\title{
AN OVERVIEW ON EMERGING WATER SCARCITY IN PAKISTAN, ITS CAUSES, IMPACTS AND REMEDIAL MEASURES
}

\author{
Salim Khoso \\ Quaid-e-Awam University College of Engineering, Sciences \& Technology (QUCEST) \\ Farhan Hussain Wagan \\ Quaid-e-Awam University College of Engineering, Sciences \& Technology (QUCEST) \\ Abdul Hanan Tunio \\ Assign Engineering Consult Intl. \\ Abdul Aziz Ansari \\ Quaid-e-Awam University College of Engineering, Sciences \& Technology (QUCEST)
}

Apparently with two thirds of the earth's surface covered by water, it is evidently clear that water is one of the most important elements responsible for life on earth. It is not only vital for sustenance of life, but equally essential for socio-economic development. Water is the unique gift of God and the basic requirement of life. Due to the high indulgence and exploitation of human being with nature, the global environment is changing every day. As a result the water resources are depleting gradually. The global fresh water shortage and food security issues related to the teeming billions of population necessitated the shifting of fresh water from agriculture to other more pressing uses. The country is facing the worst ever crises of water shortage for last many years, as water available for any given use has become increasingly scarce. The rapidly growing population, expanding of irrigation areas, and growing urban \& Industrialization are putting more stresses on water resources. Therefore, building of more reservoirs and an effective management strategy are the needs of time. The problem of water shortage particular in Sindh is crucial as being the end user and lower riparian on the Indus basin irrigation system.

Key words: Water Shortage; Agriculture; Power generation; economy; Seepage; Indus River Basin

\section{INTRODUCTION}

Water is a fundamental basic need and an essential resource for economic activities with strong cultural and symbolic values for millions of people especially in developing countries. A domestic water supply is universally acknowledged as not only a basic right but a key development indicator. One third of the world's population is currently experiencing some kind of physical or economic water scarcity. A growing competition for water from different sectors, including industry, agriculture, power generation, domestic use, and the environment, is making it difficult for people to access this scarce resource for productive, consumptive and social uses. In water-scarce regions and countries, inequity in access to water resources is increasing because of competition for limited resources, and this particularly affects poor rural people.
Although large scale water resources development has been taking place in the world, but until vast majority of people shall do not have enough potable water for drinking and canal water for irrigation. According to researchers water supply consists of making water available for agricultural urban use. Agricultural uses include irrigation, watering and farm household use. By law of supply and demand, water will be inexpensive when it is abundant and expensive when it is scarce (Adebayo A. 2007). The distribution of water supply for drinking purpose is quite appalling in modern times. Mean time the downstream people are not suitably protected against flood or disaster hits due to the improper management. Irrigation is the main stay of Pakistan's economy, around $90 \%$ of total agriculture output of the country is totally dependent on irrigation. It is clear that water resources have played very 
important role in the development of land and water storage system. More than half of world's population lives in developing countries and the poorest of these communities depend heavily on exploitation of local water resources for their livelihood.

\section{IMPORTANCE OF AGRICULTURE IN PAKISTAN}

Agriculture is important sector in the development of country, taking broader perspective on contribution of agriculture to gross domestic production and including associated support services. Agriculture is of immense importance for Pakistan. At the time of independence Pakistan was primarily agriculture based country. But as time progressed Pakistan turned into more diversified country as industrialization took hold. But development of industries had not eliminated the existence of agriculture in Pakistan although the share of agriculture had decreased significantly since its birth. The role of agriculture in the economic development of Pakistan cannot be denied and Pakistan is still characterized as an agricultural country (Sarvesh Chauhan 2013). Agricultural sector of Pakistan has made significant contribution to its GDP. When the GDP of a country grows, economic development takes place. The agriculture actually accounts the major portion of the total economy of Pakistan with $21 \%$ contribution to GDP and more than $45 \%$ contribution in labour force. It is also the major source of foreign exchange incomes in Pakistan. The export of rice, cotton, cotton based products etc. bring about $65 \%$ of our total earnings. The imports help in vital inputs for development i.e. import of equipment, capital machinery, and technical know-how etc. Agriculture is one of the main cause of employment in Pakistan, more than the half of the population of Pakistan lives in rural areas. In the development report of World Bank (2010) 63\% lived in rural areas of the total population. In Pakistan $70 \%$ of the population depends directly upon agriculture and is their main resource for livelihood as food and fibre is the basic need of the country. Improvement in agriculture productivity is must for food security, at present from 80 Mha geographical Area, 29.6 Mha is suitable for agriculture and from that 13.3 Mha is canal irrigated and 3.5 is rain fed. Agriculture acts as an industry and it is gaining recognition for its importance in combating wide spread rural poverty and acts as stabilizing factor in the national economy. It is clear from the above facts that it becomes indispensable to manage water resources and agriculture properly.

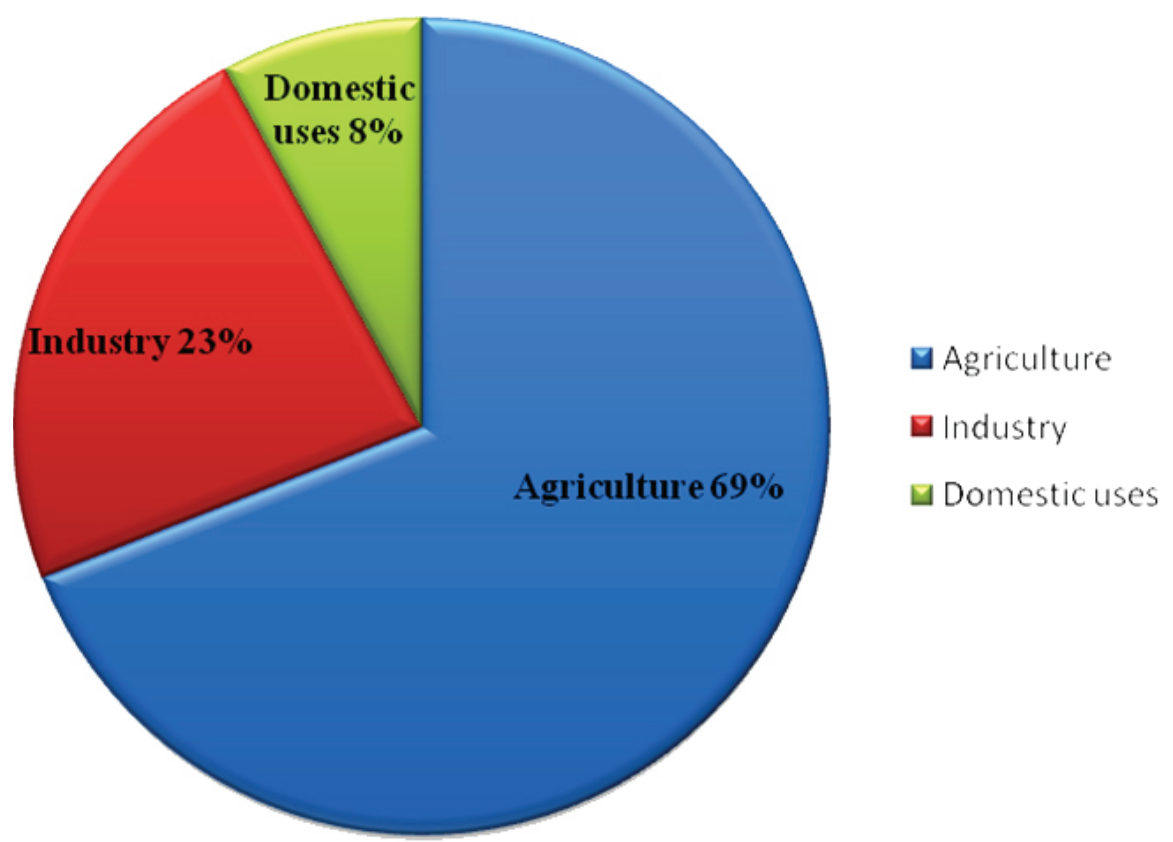

Figure 1: Total water consumption by different sectors in Pakistan 
Table 1: Distribution of water for many purposes and their quantities

\begin{tabular}{|c|c|c|c|}
\hline S. No. & Description & Purpose & Quantity \\
\hline \multirow{2}{*}{1} & \multirow{2}{*}{ Human need } & Drinking & $\begin{array}{c}3 \text { to } 5 \text { liters per capita per } \\
\text { day }\end{array}$ \\
\hline & & House hold & $\begin{array}{c}200 \text { to } 400 \text { liters per capita } \\
\text { per day }\end{array}$ \\
\hline 2 & Irrigation & $\begin{array}{l}\text { Irrigation water converted to va- } \\
\text { pour through biophysical process }\end{array}$ & $\begin{array}{l}2000 \text { to } 5000 \text { liters per } \\
\text { capita per day }\end{array}$ \\
\hline \multirow{3}{*}{3} & \multirow{3}{*}{ Industrial use } & $\begin{array}{c}\text { One automobile coming from as- } \\
\text { sembly }\end{array}$ & $\begin{array}{c}\text { Needs } 150,000 \text { liters of } \\
\text { water }\end{array}$ \\
\hline & & Refining of each liter of gasoline & Needs 300 liters of water \\
\hline & & $\begin{array}{l}\text { Thermal conversion of each kilo- } \\
\text { watt hour energy generation }\end{array}$ & Needs 225 liters of water \\
\hline
\end{tabular}

\section{WATER RESOURCES IN PAKISTAN}

\section{Rainfall}

The major sources of rainfall in Pakistan are Western depressions (December-March) and Monsoons (July-September). During the seasons of Kharif and rabi, the entire Indus plain receives an average rainfall of $212 \mathrm{~mm}$ and $53 \mathrm{~mm}$ respectively (Enum Naseer 2013).

\section{Glaciers}

Nearly $13,680 \mathrm{sq}-\mathrm{km}$ of the total area of Pakistan, is covered by glaciers that help to boost the river turnoff in warm weather. According to scientists, in just a period of 30 years, glaciers in the Himalayas have diminished by nearly onefifth and it is believed that glaciers in this region will have disappeared by 2035 and the impact of which will be devastating for the 1.3 billion people living in downstream river basins provides food and energy (Enum Naseer 2013).

\section{The Indus River System}

Fed by the glaciers of the Hindu Kush and the Karakoram, Indus is the largest river of Pakistan and the primary source of freshwater. It helps fulfill household and industrial needs and support nearly $90 \%$ of agriculture. The eastern tributaries of the Indus are Jhelum, Ravi, Chenab and Sutlej. According to the Indus Water Treaty (1960), India was given control over Bias, Ravi and Sutlej due to which they are left with less water as they flow into Pakistan. There are number of small rivers which join the west of the Indus of which biggest river is Kabul. Other rivers include Swat, Tochi, Kurram and Gomal (Enum Naseer 2013).

\section{CAUSES OF WATER SCARCITY}

\section{Less downpour}

The Hydrological cycle determines the set of processes that maintains the flow of water through the system. The hydrological cycle depend upon evaporation, due to high contamination of wet lands, oceans, rivers the process is affected badly. The contribution of rainfall to crops is $5 \%$ to $10 \%$. Cutting of large areas of jungle according to UN report in Pakistan from 7000 to 9000 hectares jungle is removed yearly and now it is only $5 \%$ instead of $25 \%$ of Total land.

\section{Silting of reservoirs}

Scarcity of water and the crippling load shedding have infuriated the nation and caused the nation of billions of dollars loss. But no one has paid attention to the silting of reservoirs that destroys reservoir lifespan, the source of water that severely affects agricultural development. Silting is equally dangerous as shortage of water and power if not more. Tarbela and Mangla the biggest reservoirs in Pakistan are facing lot of problems due to silting up to 6.6 million acre feet (MAF) in 36 years. This is alarming. Rapid silting of reservoirs has adversely affected the storage created under the Indus Water Treaty. The lost replacement of storage due to silting created under the Indus Waters Treaty urgently requires to be replenished, as part of the Indus Waters Treaty. Silting of reservoirs destroys storage capacity and adversely affects agricultural production for which dams are built and water is stored. Similarly, flood control like silt control is equally vital to avoid losses of life and property in billions of dollars and preserve water for agriculture. 
Table 2: List of main reservoirs of Pakistan and their capacity.

\begin{tabular}{|c|c|c|c|}
\hline S. No & Reservoir & Location/Near City & Total Storage \\
\hline 1 & Tarbela & Abotabad & 10.2 \\
\hline 2 & Mangla & Mirpur & 5.6 \\
\hline 3 & Hub & Malir & 0.0924 \\
\hline 4 & Tanda & Kohat & 0.0788 \\
\hline 5 & Khanpur & Khanpur & 0.059 \\
\hline 6 & Warsak & Peshawar & 0.0475 \\
\hline 7 & Rawal & Islamabad & 0.0475 \\
\hline
\end{tabular}

a)

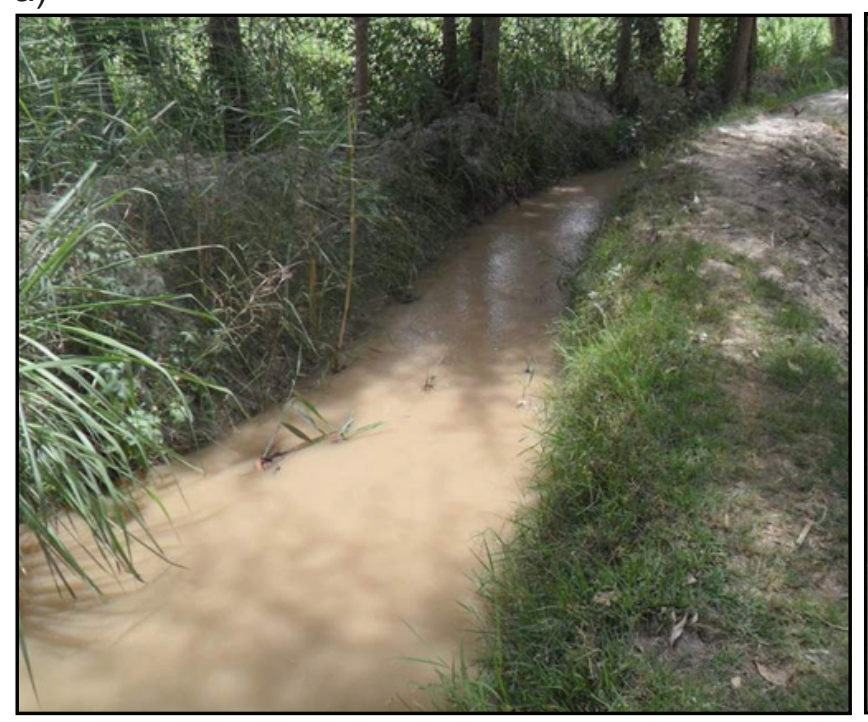

b)

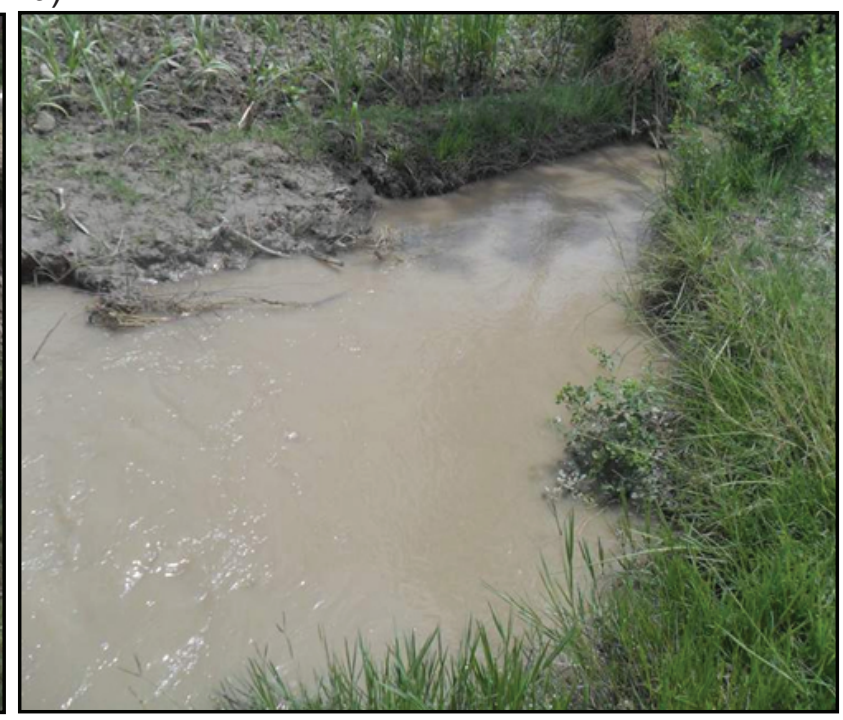

Figure 2: Views of two different unlined watercourses in Village Haji Ali Nawaz Khoso, Noorpur, Sindh

The total loss due to silting in reservoirs is about 13.20 MAF. Table 2, shows the list of main reservoirs of Pakistan and their capacity to store water (Fateh ullah Khan Gandapur 2010).

Seepage is defined as the process of movement of water from the bed and sides of canals and water courses into the soil. In Pakistan seepage losses are usually high and are about 8 to 10 cusecs per million square foot of the wetted area of the cross section and amounts to 35 to $40 \%$ of diversion into the canal. The total length of canals and watercourses in Pakistan is $56073 \mathrm{~km}$ and 1.6 million $\mathrm{km}$ respectively. Studied carried out that indicate a total annual loss of 18.3 MAF of valuable irrigation water to the ground from unlined canals and watercourses in Pakistan through seepage alone. This huge loss of supplies if prevented can irrigate approximately an additional 3.0 million acres annually.

The Indus river system is prime source of irrigation water in Pakistan. If we reduce the losses from canals and water courses, more area can be cultivated. It is estimated that about $25 \%$ water (26 MAF) is lost through canals, distributaries and minors. And about (45 MAF) water is lost from water courses through seepage, evaporation, transpiration and overtopping etc.

\section{Seepage of water}

Seepage is defined as the process of movement of water from the bed and sides of canals and water courses into the soil. In Pakistan seepage losses are usually high and are about 8 to 10 cusecs per million square foot of the wetted area of the cross section and amounts to 35 to $40 \%$ of diversion into the canal. The total length of canals and watercourses in Pakistan is $56073 \mathrm{~km}$ and 1.6 million $\mathrm{km}$ respectively. Studied carried out that indicate a total annual loss of 18.3 MAF of valuable irrigation water to the ground from unlined canals and watercourses in Pakistan through seepage alone. This huge loss of supplies if prevented can irrigate approximately an additional 3.0 million acres annually.

The Indus river system is prime source of irrigation water in Pakistan. If we reduce the losses from canals and water courses, more area can 
be cultivated. It is estimated that about $25 \%$ water (26 MAF) is lost through canals, distributaries and minors. And about (45 MAF) water is lost from water courses through seepage, evaporation, transpiration and overtopping etc.

\section{GLOBAL POPULATION POSITION UN ESTIMATED}

The global population in 2006 was 6.7 billion, which is increasing at a rate of 78 million/year that has reached 7.13 billion now. It has been predicted that the population will reach up to 10.9 billion by the year 2050. Among all this total population, $90 \%$ growth rate occurs in developing countries; already such countries like Pakistan are facing many problems of food, fibre, health and education. Increase in population will put an enormous pressure on water use. Pakistan is 6th most populous nation in the world with 19.6 million population growing at a rate of $1.52 \%$ by the year 2014 (The World Fact book 2014).

\section{INDUS WATER TREATY}

Soon after 1947, the dispute of water distribution arose between Pakistan and India. The treaty was signed through World Bank in 1960. This treaty divided the use of rivers and canals between the two countries. Pakistan obtained exclusive rights for the three western rivers, namely Indus, Jehlum and Chenab. And India retained rights to the three eastern rivers, namely Ravi, Beas and Sutluj. The treaty also guaranteed ten years of uninterrupted water supply. During this period Pakistan was to build huge dams, financed partly by long-term World Bank loans and compensation money from India. Three multipurpose dams, Warsak, Mangla and Tarbela were built. A system of eight link canals was also built, and the remodeling of existing canals was carried out. Five barrages and a gated siphon were also constructed under this treaty. Total water sold 24MAF, irrigating some Area of 8MA of land. The IWT took place in 62 million pounds and it was a big loss to the country making the water scarcer (Story of Pakistan 2003).

\section{WATER LOSSES}

The tree below shows total water collected from all the surface sources in Pakistan and the losses from canals, watercourses and lands.

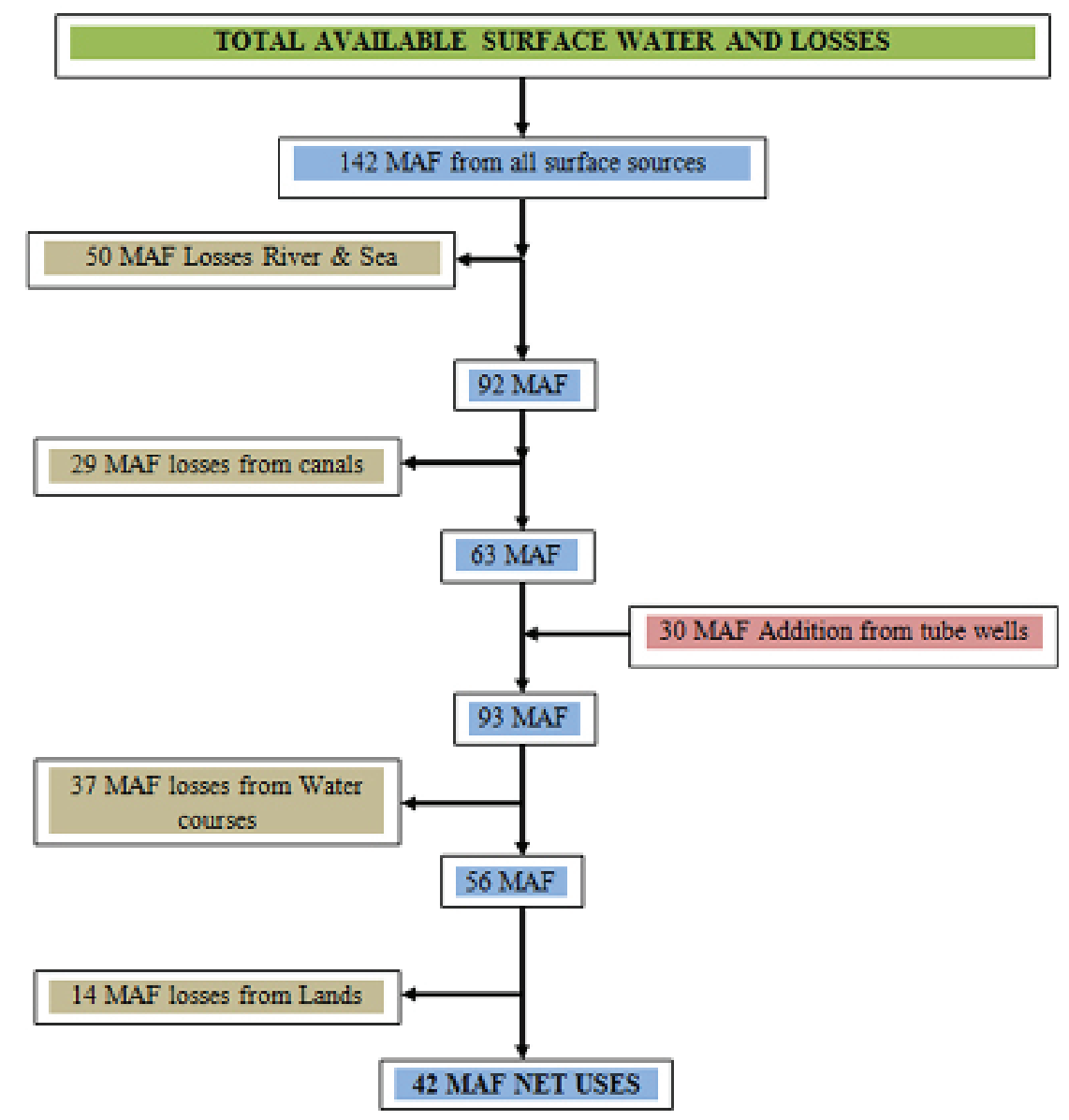




\section{DISCUSSION}

No kind of irrigation engineering work can be under taken without ample knowledge of the water availability. A correct estimate of available water for irrigation is a pre-condition of success. In addition quality and quantity of water has to be assessed before its utility. The water supply available for agriculture is derived from freezed ice, surface storages and ground entrapment. But the actual and only recharging source is the rainfall. Rainfall is normally inadequate to sustain more than a very low level of agricultural production, particularly in semi-arid regions. This requires the effective watershed management for harvesting the surface and sub-surface runoff and preparation of water budget from all sources. The irrigation water is becoming a diminishing source in Pakistan and the whole world. It is clear from the global facts that for sustainable and further development of the agriculture sector, storages are must at proper places with proper planning and management.

\section{IMPACT OF WATER SHORTAGE}

\section{Shortage in cropped land}

Due to the water shortage out of 80 million hectares of land (Mha), 29 Mha land is cultivable but only 17 Mha is hardly canal irrigated yet, therefore import of food grains put additional stress on economy. The major crops of Pakistan include wheat, rice, maize, millets, sorghum, sugarcane, pulses, cotton, oilseeds. Pakistan is home to the aromatic long grain Basmati rice, grown in the plains of north Punjab. Some of the best varities of fruits are grown in Pakistan that include mangoes, apples, oranges, peaches, plums, apricots, cherries, grapes, pears, pomegranate, guava, melons and dates. A wide variety of vegetables are also produced in Pakistan. But the water shortage in the present situation can put enormous reduction in the mentioned productions and put impact on economy of the country.

Table 3: List of in service Thermal stations and their energy generation capacity

\begin{tabular}{|c|c|c||c|c||}
\hline \multicolumn{5}{|c|}{ Thermal Power stations in service } \\
\hline \hline S. No. & Station & Location & $\begin{array}{c}\text { Capacity } \\
\text { (MW) }\end{array}$ & Source \\
\hline 1 & Hub Power company Plant & Hub Balochistan & 1292 & Oil fired thermal station \\
\hline 2 & Hub Power project Narowal & Narowal Punjab & 225 & Furnace oil fired plant \\
\hline 3 & Bin Qasim Power Plant I & Karachi, Sindh & 1260 & Oil and Natural gas fired plant \\
\hline 4 & Jamshoro Power Station & jamshoro, Sindh & 1054 & Oil and Natural gas fired plant \\
\hline 5 & lalpir Limited & Muzaffargarh, Punjab & 362 & Oil fired thermal station \\
\hline 6 & Altern Energy limited & Fateh Jang, Punjab & 29 & Gas fired Diesel Engine \\
\hline 7 & Atlas Power Limited & Sheikhupura, Punjab & 225 & Furnace oil fired plant \\
\hline 8 & Attock Gen Limited & Rawalpindi, Punjab & 165 & Furnace oil fired plant \\
\hline 9 & Fauji Kabirwala company & Kabirwala, Punjab & 157 & Combined cycled, gas fired \\
\hline 10 & Gulant \\
\hline 11 & Nishat Power Limited & Lahore, Punjab & 200 & Furnace oil fired plant \\
\hline 12 & Nishat Chunian Limited & Lahore, Punjab & 200 & Furnace oil fired plant \\
\hline 13 & Sapphire Electric Company & Muridke, Punjab & 225 & Furnace oil fired plant \\
\hline 14 & Saba Farooq Company & Farooqabad, Punjab & 125 & Furnace oil fired plant \\
\hline 15 & Southern Electric Power & Raiwind, Lahore & 135 & Furnace oil fired plant \\
\hline 16 & Tapal Energy Limited & Karachi, Sindh & 126 & Furnace oil fired plant \\
\hline 17 & Japan Power Generation & Raiwind, Lahore & 135 & Furnace oil fired plant \\
\hline 18 & Kohinoor Energy Limited & Lahore, Punjab & 131 & Furnace oil fired plant \\
\hline 19 & Sitara Energy Limited & Faisalabad, Punjab & 85 & Diesel \& Natural gas fired Plant \\
\hline 20 & Saif Power Limited & Sahiwal, Punjab & 225 & Diesel \& Natural gas fired Plant \\
\hline
\end{tabular}




\section{Hydro Power}

Pakistan has an estimated potential of 40,000 MW of hydropower in the upper Indus region; we have tapped only $13 \%$. At present Pakistan has an installed electricity generation capacity of $22,797 \mathrm{MW}$. The average demand is $17,000 \mathrm{MW}$ and the shortfall is between 4,000 and $5,000 \mathrm{MW}$. Oil (35.2 per cent), hydel (29.9 per cent), gas (29 per cent), and nuclear and imported (5.8 per cent) are the principal sources (Zakir Kazmi 2014). WAPDA has projected a power requirement of 75149 MW by year 2025, which can only be achieved by constructing additional storage dams. Table 3, shows in service thermal power stations in Pakistan and their energy generation.

\section{Effects of Urbanization}

Pakistan's estimated population in 2014 is over 190 million making it world's 6th populous country. Due to the fast pace in the growth of population, urbanization is increasing which will put an enormous pressure on the social demography of the country where the cities are growing at an unprecedented speed. In this case people need water for their survival, but water scarcity in turn is affecting the availability of water badly. With the increase in water shortage, the society will witness tremendous problems in the coming times.

\section{Ground Water}

Shortage of surface water has put tremendous pressure on ground water. Over drawing of ground water by users to compensate the shortage. In turn reduced recharging owing to less percolation. This has resulted rising of saline water lens nearer to the ground surface.

\section{Effect on National Harmony}

The worst impact of water shortage is that, it is creating bitter controversy between provinces, which is affecting national integration and creating disharmony between provinces.

\section{Intrusion of Salt Water}

The Indus water discharge to the sea keeps the sea water at bay and does not let it intrude too much into the surface and subsurface water resources inland. With the current water shortage the situation is deploring. Salt-water intrusion has been witnessed inland up to 100 kilome- ters north of the sea. The Laar area of Sindh is adversely affected. The salt-water intrusion destroys water supplies and people are compelled to drink brackish water and thus exposed to various diseases. Throat swelling due to drinking salty water is a common complaint witnessed in the coastal areas of Sindh. Furthermore, seawater renders fertile agricultural lands useless, resulting in loss of jobs and economic devastation. Hundreds of villages in the Badin and Thatta districts have been deserted and people have been forced to migrate to some other areas (Altaf A. Memon 2002).

\section{Coastal Land Lost}

Due to continuous increase in the Indus withdrawals in Punjab, the outflow to sea has reduced to a great deal. Consequently, the costal ecosystem has been damaged. The degeneration of the natural resources has deteriorated human settlements compelling plenty of people of the coast to migrate to other areas in search of water and food. Former Sindh Minister of Irrigation, Ali Mir Shah, provided results of a survey conducted by the government of Sindh that over1.2 million acres land were eroded or lost to the sea within Thatta and Badin districts, dislocating a quarter million people, and inflicting financial losses over Rs.100 billion. The seawater had destroyed at least one-third of the land. 12 Recent estimates put the figure at 1.4 million acres of the land lost to the sea. Further 13 loss of land due to erosion and seawater is not out of the question as the water shortage continues unabated (Altaf A. Memon 2002).

\section{Impact on Economy / Society}

Agriculture is the backbone of the country and the water flowing in the channels to the crops is its blood line. If there is shortage of water then the country should be prepared for facing problems economically as well as socially. According to the estimates of federal government, the agriculture sector would suffer a loss of about Rs. 90 billion because of drought. Since agriculture has remained a major source of shouldering the already crippled economy, it has a vital role to play particularly in terms of food security and employment of the everburgeoning population of the country. The adverse effects of water shortage on agriculture would have a spiraling effect on the prevailing level of poverty (Water crisis in Pakistan and its remedies 2014). 


\section{REMEDIES TO THE PRESENT WATER SHORTAGE}

Pakistan is agricultural region water is key for survival, water is lost due to mismanagement mainly. A big investment in the repair of existing dams and the large scale construction of new water storage is simple solution of problem. In managing water resources, the government of Pakistan must balance competing demands between urban and rural, rich and poor, the economy and the environment. However, because people have triggered this crisis, by changing their actions they have the power to prevent water scarcity from devastating Pakistan's population, agriculture, and economy.

\section{Effective management}

Managing water resources is the need of time, and Pakistan is already facing shortage in water. The solution of this can save around 1.3 MAF of water from existing losses. Following are the recommendations in this regard:

- Most of the water is lost due to seepage, infiltration and leakages etc. Seepage results in water logging eventually making the land less fertile. These losses can be eliminated by lining the canals and watercourses.

- In addition, people should be educated and aware to conserve water by cooperation and using it efficiently.

- Like many western countries the government should make laws on water conservation.

- The second largest contribution to the total water available comes from the groundwater sources. This source has been exploited and very well used by public and private tube wells. It can still provide over 9 MAF of water. This source can be exploited and judiciously used for irrigation purposes. However in some areas ground water is rapidly depleting due to excessive pumping of water with tube wells, authorities should take control in such areas to save them from depleting and to use sources for recharging them.

- Efforts should be made to convert the present rotation based irrigation system to demand oriented system.

- There should be proper use of irrigation water and can be controlled by adopting modern irrigation techniques, that is trickling, sprinkling etc, which have a potential to im- prove water distribution and its utilization.

- Waste water should be re-used for the irrigation purpose.

- Authorities should take appropriate steps to curb the illegal extraction of water and ensure its equitable distribution.

- Presently irrigation department has failed to stop the illegal theft and extraction; thus irrigation distribution system needs to be privatized through water user associations.

- In addition, water, now-a-days is supplied to farmers at a very negligible cost and that is why they do not treat water as a precious resource; therefore there is a need to increase the water prices to make irrigators realize the importance of this asset.

- Farmer's organizations, water user association, and private sector be involved in construction, operation, and maintenance of the irrigation system. Such associations are conceived as a mechanism for creating a cooperative frame work for improvement of watercourses.

\section{Investigation}

- There should be Feasibility investigation of required sources in detail.

- Study for River basin development should be done for its all parameters.

- There should be Regional development policy applicable to the area using water.

- National development policy should be initiated in light of water rules.

- The above mentioned investigations are necessary to conduct that will help the socioeconomic and environmental development.

\section{RECOMMENDATIONS}

- Food and fibre is the pressing need of every one, therefore proper management of water resources is necessary.

- Statistics of yearly water budget will help in effective planning of water resources.

- A one century old irrigation system is now posing the serious problem of water wastage through seepage; it requires proper rehabilitation at required level.

- The water users be awared properly about the importance, availability and effective use of water through social mobilization. 
- Institutional management, effective planning and wise use of water is the requirement of time.

- Furrow as method of cultivation and trickle as method of irrigation be implemented effectively.

- Water rights, rules and policies be framed to control wicked problems like tampering of modules, water theft and pilferage etc.

- Instead of land tax, now Tax be fixed on water quantity

\section{CONCLUSIONS}

More than $70 \%$ of the population lives in rural areas and the poorest of these communities depend heavily on exploitation of local natural resources for their livelihoods. Management becomes important when the productive resource is water and depleting day by day. Awareness through all possible means about the environment calls for reduced abstraction and higher quality return flows. A national policy is necessary to achieve sustainable agriculture growth. The problem of water shortage be investigated up to its grassroots, then on the basis of that an effective solution be produced and implemented. Growing urban concentration and industrialization along the rivers on one side led to the significant abstraction of fresh water and on other side put negative impacts on water quality. Therefore water balance, water quality and water accounting is must for sustainable water supply for all possible uses. Agriculture had contributed in Pakistan's development in these various ways. The government should announce policies which raise the productivity of agriculture in order to increase economic development. Government should familiarize modern ways of production through the introduction of technology in the area of agriculture. The government should also study land reforms as the large lands are more productive than the small ones and should also increase the ownership of land to remove feudalism. Effective and operative ways for agricultural sector will definitely enhance the development of the weak economy of Pakistan.

Salim Khoso is presently working as a lecturer in Quaid-e-Awam University college of Engineering, Science and Technology, Larkana, Sindh, Pakistan. He has completed his bachelor's degree from the same university and has done his Master's degree in Design of Steel Structures from University of Naples Federico II, Naples, Italy. $\mathrm{He}$ is working on Seismic design of Steel structures, concrete structures and having an interest in Irrigation too. Mr Salim is an author of 4 publications that are presented in national conferences and published internationally. $\mathrm{He}$ is a member of Pakistan engineering council (PEC).

\section{REFERENCES}

1) Adebayo, A. (2007) Adaptive Water Management System in Nigerian Peri-urban Center, A paper presented at 4th Annual Association of Nigerian Geographers conference, held at University of Abuja, Nigeria, 15th -19th October, 2007

2) Allan, J.A. (1999) Productive efficiency and allocate efficiency: why better water management may not solve the problem, Agricultural Water Management 40,71-75.

3) Burton, M. (1999) Note on proposed framework and activities, Prepared for the IWMI.DSI.CEVMBER Research Programme on Institutional Support Systems for Sustainable Management of Irrigation in Water - Short Basins, Izmir.

4) Clarke, R. (1993) Water: The International Crisis Earth scan, London.

5) Cleaver, F. (1999) Paradoxes of participation: questioning participatory approaches to development, Journal of International Development 11, $597-612$.

6) Enum Naseer (2013) Pakistan's Water Crisis, Spread head Research Special Report

7) Gandapur Fateh Ullah Khan (2010) Silting is destructive for life of reservoirs and for agricultural development, Fateh Gandapur's blog on Water issues in Pakistan.

8) Heathcote, I.W. (1998) Integrated Watershed Management. Principles and Practice. John Wiley and Sons, New York.

9) Iqbal Ali (1993) Irrigation and Hydraulic Structures Theory, design and practice.

10)Marella L. Richard (1998) Water Use Trends and Demand Projections in the Northwest Florida Water Management District, U.S. Geological Survey.

11)Mehta, I., (2000) Water for the twenty-first century; challenges and misconception, IDS Working Paper 111, IDS, Brighton. 
12)Memon A. Altaf (2002) An Overview of the History and Impacts of the Water Issue in Pakistan, Proceedings of International Conference on "Sindh, the Water Issue and the Future of Pakistan," The World Sindhi Institute, November 9, Washington, DC, 2002

13)Molden, D. (1997) Accounting for water use and productivity, SWIM Paper No.1, International Irrigation Management Institute, Colombo, Sri Lanka.

14)Sarvesh Chauhan (2013) The Role of Agriculture in Economic development of Pakistan, http://www.scribd.com/doc/47709856/Roleof-Agriculture-in-Economic-Development, retrieved on 28.01.2011
15) Story of Pakistan (2003) Indus Water Treaty, http://storyofpakistan.com/indus-water-treaty/, retrieved on 1.06.2003.

16)Walton, W.K. (1970) The World of Water, Weilder Feld and Nicolson, London.

17)Water crisis in Pakistan and its remedies (2014),http://www.pakissan.com/english/watercrisis/water.crisis.in.pakistan.and.its.remedies.shtml, retrieved on 14.07.2014

18)Zahir Kazmi (2014), Pakistan's Energy Security http://tribune.com.pk/story/655573/pakistansenergy-security/, retrieved on 07.01.2014

Paper sent to revision: 14.07.2014.

Paper ready for publication: 09.03.2015. 